\title{
KALIMAT LARANGAN DALAM BAHASA JAWA
}

\section{PROHIBITION SENTENCE IN JAVANESE}

\author{
Herawati \\ Balai Bahasa Daerah Istimewa Yogyakarta \\ Jalan I Dewa Nyoman Oka 34 Yogyakarta \\ Pos-el: herawati.2013.bby@gmail.com \\ Telepon 081328751032
}

\begin{abstract}
Abstrak
Kalimat larangan merupakan subbagian dalam kalimat imperatif atau perintah. Makna ujaran yang bersifat melarang diungkapkan dengan bentuk imperatif negatif aja 'jangan'. Teori yang dipergunakan adalah teori struktural. Metode yang dipergunakan metode distribusional dengan teknik parafrasa atau pengubahan bentuk atau sinonimi gramatikal, dan substitusi. Hasil pembahasan kalimat larangan meliputi (a) struktur internal kalimat larangan yang membedakan dengan bentuk kalimat lainnya, (b) jenis konstituen yang mendukung terbentukya kalimat larangan, dan (c) status argumen pada konstituen pengisi fungsi subjek yang membedakan subjenis kalimat larangan yang satu dengan subjenis kalimat larangan yang lain.
\end{abstract}

Kata kunci: kalimat larangan, diatesis, argumen

\begin{abstract}
Prohibition Sentence is part of the imperative sentence or order sentence.Prohibition speech meaning is expressed in form of negative imperative wrote aja 'do not'. The theory in this research is structural theory. The method of research is distributional method with paraphrasing technique or shape changing or grammatical synonymy, and substitutions. Result shows that prohibition sentence includes (a) the internal structure of prohibition sentence that distinguishes it from other sentence form, $(b)$ the type of constituent that supports realization of prohibition sentence, and (c) argument status on the sfiller constituent of subject function which differentiates one subtype of prohibition sentence with other prohibition sentence subtypes.
\end{abstract}

Keywords: prohibition sentence, diathesis, argument

\section{Pendahuluan}

Kalimat larangan bahasa Jawa pernah dibicarakan sekilas oleh Antunsuhono (1956: 36-37) dalam bukunya berjudul Reringkesaning: Paramasastra Djawa II. Kalimat larangan merupakan subbagian dari kalimat perintah. Menurut buku Tata Bahasa Baku Bahasa Indonesia (Alwi, 2003:353-357) kalimat larangan merupakan subbagian dalam kalimat imperatif. Kalimat perintah ditinjau dari isinya dapat dirinci menjadi enam golongan, yaitu (1) perintah atau suruhan, (2) perintah halus, (3) permohonan, (4) ajakan dan harapan, (5) larangan atau perintah negatif, dan (6) pembiaran. Kalimat larangan atau perintah negatif, jika pembicara menyuruh agar jangan dilakukan sesuatu (Alwi, 2003:353). Selanjutnya, Ramlan (1987: 46-49) menjelaskan bahwa kalimat larangan merupakan subbagian kalimat suruh. Berdasarkan strukturnya kalimat suruh dapat digolongan menjadi empat golongan, yaitu: (a) kalimat suruh yang sebenarnya, (b) kalimat persilakan, (c) kalimat ajakan, dan (d) kalimat larangan. Kalimat larangan ditandai oleh pola intonasi suruh dan ditandai juga oleh adanya kata jangan di awal kalimat. Partikel lah dapat ditambahkan pada kata tersebut untuk memperhalus larangan, misalnya, Jangan engkau berangkat sendiri! Antunsuhono (1956: 36-37) mengatakan bahwa ukara larangan iku pada bae karo 
ukara, mung bae sarana diwuwuhi tembung aja, hajwa. 'Kalimat larangan itu sama dengan kalimat hanya saja diberi kata aja dan hajwa'. Beliau menjelaskan secara pintas bahwa kalimat larangan sama dengan kalimat perintah (ukara pakon) dengan penambahan kata aja 'jangan' dan haywa 'jangan', seperti tampak pada contoh kalimat berikut.

\section{(1) Aja udud ing jero kelas. 'Jangan merokok di dalam kelas' \\ (2) Haywa anguntjireng yuda! 'Jangan menghindari perang!'}

Selanjutnya, Ramlan $(1987: 137)$ menjelaskan konstituen negatif dalam bahasa Indonesia meliputi tidak, tak, tiada, bukan, belum, dan jangan; Herawati (2007) juga menjelaskan bahwa kata aja'jangan' merupakan konstituen negatif atau ingkar digunakan untuk menegatifkan predikat yang berwujud kata atau frasa verbal, numeralia, adjektiva, dan frasa preposisi. Konstituen negatif aja ini lazimnya berfungsi sebagai penunjuk imperatif negatif

Perlu diketahui bahwa kalimat larangan merupakan subbagian dari kalimat perintah dan memiliki jenis kalimat bawahan. Adapun jenis kalimat bawahan itu didasarkan pada Diatesis Bahasa Jawa yang ditulis Sudaryanto (1991). Diatesis sering disebut voice dalam bahasa Inggris (Lyons, 1969:372 dalam Sudaryanto, 1991:1). Yang dikenal adalah active voice dan passive voice atau diatesis aktif dan diatesis pasif. Diatesis adalah kategori gramatikal yang menunjukkan hubungan antara partisipan atau subjek dan perbuatan yang dinyatakan oleh verba dalam klausa (Kridalaksana (2001:43). Jadi, diatesis menyangkut masalah sintaksis dan menyangkut semantik (Sudaryanto 1991:1) membagi menjadi empat bagian, yaitu (1) diatesis aktif, (2) diatesis pasif, (3) diatesis refleksif, dan (4) diatesis resipokral. Diatesis aktif, misalnya, bersangkutan dengan klausa yang predikat verbanya adalah aktif dengan subjek pelaku atau agen atau agentif. Demikian pula diatesis pasif berhubungan dengan klausa yang predikat verbanya pasif dan subjek penderita. Diatesis refleksif merupakan diatesis yang menunjukkan 'subjek berbuat atas diri sendiri' dan diatesis resiprokal adalah diatesis yang menunjukkn subjek pluralis bertindak berbalasan atau subjek 'singularis bertindak berbalasan dengan komplemen'(lihat Kridalaksana, 2001:43). Dengan pertimbangan hal itu, penulis akan mengkaji kalimat larangan dalam bahasa Jawa.

Kalimat larangan yang dikaji oleh penulis didasarkan pada Diatesis Bahasa Jawa meliputi (1) kalimat larangan aktif, (2) kalimat larangan pasif, (3) kalimat larangan refleksif, dan (3) kalimat larangan resiprokal. Masalah yang akan dicermati dalam makalah ini meliputi (a) struktur internal kalimat larangan yang membedakan dengan bentuk kalimat lainnya, (b) jenis konstituen yang mendukung terbentuknya kalimat larangan, dan (c) status argumen pada konstituen pengisi fungsi subjek yang membedakan subjenis kalimat larangan yang satu dengan subjenis kalimat larangan yang lain.

Kerangka teori yang digunakan dalam makalah ini berdasarkan teori yang dikemukakan Ramlan (1987) dan Sudaryanto (1991) tentang Diatesis dalam Bahasa Jawa. Menurut Ramlan (1987:49) kalimat larangan ditandai oleh pola intonasi suruh 23 \# atau 232 \# dan ditandai oleh adanya kata jangan di awal kalimat, misalnya, Jangan engkau membaca buku itu!

Kalimat larangan berhubungan dengan jumlah dan jenis partisipan atau argumen serta wujud morfemis kata kerja/verba pengisi fungsi predikat. Istilah subjek, predikat, dan objek untuk menyebut fungsi sintaktik (slot) yang bersifat inti yang diisi oleh argumen tertentu. Istilah partisipan menurut Kridalaksana (2001:156) adalah argumen dalam konfigurasi; nomina dalam hubungannya dengan suatu peristiwa; termasuk di antaranya pelaku, tujuan, dan alat. Partisipan diidentikkan dengan istilah argumen yang konsepnya lebih bersifat kemaknaan. Dalam hubungannya dengan konsep argumen, subjek sebagai konsep imbangan bagi predikat merupakan slot atau "tempat kosong" yang merupakan salah tempat bagi argumen tertentu. Konsep 
argumen dihubungkan dengan konsep fungsi inti. Misalnya, kata kerja yang menyatakan perbuatan, maka argumen yang gayut adalah pelaku/agentif. Dengan demikian, argumen pelaku berbentuk nomina maka argumenlah yang pertama-tama diperhatikan. Apabila mengisi subjek kalau kata kerja yang menyatakan perbuatan itu ke pelaku (Sudaryanto, 1983:45). Berarti kata kerja/ verba itu bermakna aktif dan argumen pelaku sebagai subjek. Namun, argumen tidak mengisi subjek arah kata kerja itu bukan ke pelaku. Dalam kaitannya dengan hal ini, pada kalimat tertentu kata kerjanya bermakna pasif dan subjeknya penderita, tujuan, atau sejenisnya

Metode yang dipergunakan dalam makalah ini metode distribusional dengan teknik parafrasa atau pengubahan bentuk atau sinonimi gramatikal dan substitusi (Sudaryanto, 1982:13). Penerapan teknikteknik tersebut dianggap sesuai dengan pokok permasalahan yang menyangkut sintaksis. Beberapa tes gramatikal itu dilakukan untuk mengetahui perilaku sintaksis.

\section{Pembahasan Kalimat Larangan}

Kalimat larangan dalam bahasa Jawa dapat ditandai dengan penanda perintah aja 'jangan' yang berdistribusi paralel dengan konstituen negatif ora usah 'tidak usah', ora oleh 'tidak boleh', ora perlu 'tidak perlu', ora kena 'tidak boleh', ora entuk 'tidak boleh', dan kata dipenging 'dilarang' yang terletak di sebelah kiri kata kerja pengisi fungsi predikat. Kata kerja pengisi fungsi predikatnya memiliki ciri morfemis yang berbeda dengan kata kerja pengisi predikat pada kalimat perintah, misalnya, lungguh! 'duduk!, lungguha 'duduklah!'. Kata kerja pengisi predikat pada kalimat larangan berupa kata kerja indikatif. Yang dimaksud kata kerja indikatif adalah bentuk kata kerja yang paling sering dipergunakan dalam bahasa Jawa (Poedjosoedarmo, 1979:55). Kata kerja indikatif menunjukkan adanya kenyataan atau sesuatu yang berhubugan erat dengan kenyataan dan sering dipakai untuk menunjukkan modalitas imperatif dalam hal- hal tertentu. Perhatikan contoh kalimat larangan berikut ini.

$$
\text { (1) } \left.\left\{\begin{array}{l}
\text { Kowe } \\
\text { Kowe } \\
\text { Kowe sakloron } \\
* \text { Aku } \\
* \text { Dheweke }
\end{array}\right\}\left\{\begin{array}{l}
\text { aja } \\
\text { kabeh } \\
\text { ora usah } \\
\text { ora perlu } \\
\text { ora kena } \\
\text { ora entuk } \\
\text { ora oleh } \\
\text { dipenging }
\end{array}\right\} \begin{array}{l}
\text { nyilih } \\
\text { klambine } \\
\text { Tina. }
\end{array}\right\}
$$

'Kamu jangan memijam bajunya Tina'

$$
\begin{aligned}
& \text { (1a) Ø } \quad\left\{\begin{array}{l}
\text { aja } \\
\text { ora usah } \\
\text { ora perlu } \\
\text { ora kena } \\
\text { ora entuk } \\
\text { ora oleh } \\
\text { dipenging }
\end{array}\right\} \text { nyilih klambine Tina. } \\
& \text { 'Ø jangan meminjam bajunya Tina'. }
\end{aligned}
$$

Contoh kalimat (1) cenderung mengacu pada makna larangan daripada kalimat perintah. Pengisi fungsi predikat berpenanda perintah aja 'jangan' diikuti kata kerja nyilih 'meminjam', sedang argumen agentif yang mengisi fungsi subjek hadir secara formal mengacu pada persona kedua, yaitu konstituen kowe atau dapat berupa kowe kabeh'kamu semua', kowe sakloron 'kamu berdua' atau bentuk lain yang prinsipnya mengacu pada persona kedua dan tidak terlepas dari konteks kalimatnya. Konstituen kowe 'kamu' tidak berdistribusi paralel dengan konstituen yang mengacu pada persona pertama dan persona ketiga, seperti konstituen aku 'saya' dan dheweke 'dia'.

Konstituen aja 'jangan' sebagai penanda larangan merupakan unsur penting dalam pembentuk kalimat larangan, dan kehadirannya bersifat wajib. Apabila konstituen aja 'jangan' dalam kalimat larangan (1) dilesapkan maka kalimat larangan berubah menjadi kalimat berita, seperti dalam kalimat (1b).

(1b) Kowe nyilih klambine Tina.

'Kamu meminjam bajunya Tina' 
Contoh lain kalimat larangan seperti berikut.

(2) Gelange emas

$$
\left\{\begin{array}{l}
\text { aja } \text { kokdol } \\
\text { ora usah } \\
\text { ora perlu } \\
* \text { ora entuk } \\
\text { *ora oleh } \\
\text { *dipenging }
\end{array}\right\}
$$

'Gelangnya emas jangan dijual'

(3)

$$
\left\{\begin{array}{l}
\text { aja } \\
\text { ora usah } \\
\text { ora perlu } \\
\text { *ora kena } \\
\text { ora entuk } \\
\text { ora oleh } \\
\text { dipenging }
\end{array}\right\}
$$

'Ayamnya jangan diberi makan.'

(4) Lap tope $\left\{\begin{array}{l}\text { aja } \\ \text { ora usah } \\ \text { ora perlu } \\ \text { *ora kena } \\ \text { ora entuk } \\ \text { ora oleh } \\ \text { dipenging }\end{array}\right\}$

'Laptopnya jangan dipinjamkan Yani'

(5) Kowe lan adhinu $\left\{\begin{array}{l}\text { aja } \\ \text { ora usah } \\ \text { ora perlu } \\ \text { ora kena } \\ \text { ora entuk } \\ \text { ora oleh } \\ \text { dipenging }\end{array}\right\}$

'Kamu dan adikmu jangan saling berantem'

(6) Kowe $\left\{\begin{array}{c}\text { aja } \\ \text { ora usah } \\ \text { ora perlu } \\ \text { ora kena } \\ \text { ora entuk } \\ \text { ora oleh } \\ \text { dipenging }\end{array}\right\}$ lunga nganti esuk.

'Kamu jangan sampai pagi'

Kalau diperhatikan contoh kalimat (1)-(6) di atas maka akan ditemukan empat subjenis kalimat larangan, yaitu contoh kalimat (1) merupakan kalimat larangan aktif, kalimat (2), kalimat (3), dan kalimat (4) merupakan kalimat larangan pasif, kalimat (5) merupakan kalimat larangan resiprokal, dan kalimat (6) merupakan kalimat larangan reflektif. Untuk penjelasan lebih lanjut, subjenis kalimat larangan akan dibicarakan berikut ini.

\subsection{Kalimat Larangan Aktif}

Kalimat larangan aktif menuntut kehadiran konstituen subjek bersifat opsional dan berstatus argumen agentif, seperti contoh berikut.

(7) $\left\{\begin{array}{l}\text { Kowe } \\ \text { Kowe kabeh } \\ \text { Kowe saklaron } \\ * \text { Aku } \\ * \text { Dheweke }\end{array}\right\}\left\{\begin{array}{l}\text { aja } . \\ \text { ora oleh } \\ \text { ora perlu } \\ \text { ora kena } \\ \text { ora entuk } \\ \text { ora usah } \\ \text { dipenging }\end{array}\right\}$ ngengakake

'Kamu jangan membuka pintu garasi.'

(8) $\left\{\begin{array}{l}\text { Kowe } \\ \text { Kowe kabeh } \\ \text { Kowe saklaron } \\ * \text { Aku } \\ * \text { Dheweke }\end{array}\right\}\left\{\begin{array}{l}\text { aja } \\ \text { ora oleh } \\ \text { ora perlu } \\ \text { ora kena } \\ \text { ora entuk } \\ \text { ora usah } \\ \text { dipenging }\end{array}\right\} \begin{aligned} & \text { ngotori } \\ & \text { latar } \\ & \text { ngarep. }\end{aligned}$

'Kamu jangan mengotori halaman depan'.

(9) Kowe $\left\{\begin{array}{l}\text { aja } \\ \text { Kowe kabeh }\end{array}\right\}\left\{\begin{array}{l}\text { ora usah } \\ \text { ora oleh } \\ \text { ora kena } \\ \text { ora entuk } \\ \text { ora usah } \\ \text { dipenging }\end{array}\right\}$ Marni.

'Kamu jangan menyuruh Marni'

Fungsi subjek pada kalimat (7)—(9) diisi oleh konstituen kowe 'apem'atau kowe kabeh 'kamu semua', kowe saklaron 'kamu berdua' berstatus argumen agentif yang mengacu pada persona kedua. Selain itu, konstituen kowe 'kamu' sebagai pengisi fungsi subjek berargumen agentif pada kalimat (7)-(9) 
dapat dilesapkan dan kalimat itu tetap berterima, seperti dalam kalimat (7a)-(9a) berikut ini.

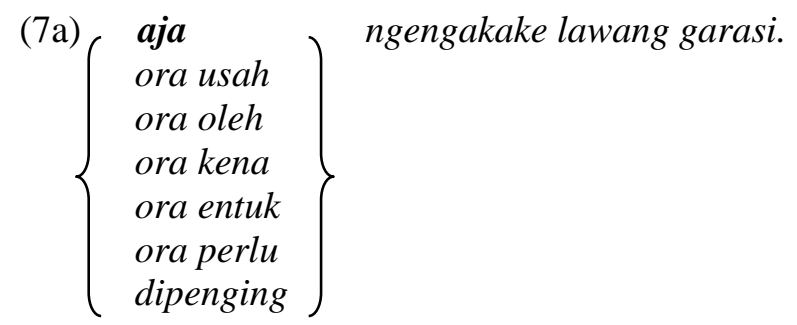

'Jangan membuka pintu garasi'

(8a)

$$
\left\{\begin{array}{l}
\text { aja } \\
\text { ora usah } \\
\text { ora oleh } \\
\text { ora kena } \\
\text { ora entuk } \\
\text { ora perlu } \\
\text { dipenging }
\end{array}\right\}
$$

'Jangan mengotori halaman depan'

(9a)

$$
\left\{\begin{array}{c}
\text { aja } \\
\text { ora usah } \\
\text { *ora oleh } \\
\text { ora kena } \\
\text { ora entuk } \\
\text { ora perlu } \\
\text { dipenging }
\end{array}\right\}
$$

'Jangan menyuruh Marni'

Perlu diketahui bahwa ciri-ciri morfemis kata kerja pengisi fungsi predikat pada kalimat larangan aktif, yaitu kata kerja indikatif berprefiks $N$-, sedang akhiran -ake dan $-i$ dalam kalimat larangan mengacu pada jeis argumen pengisi objek atau pelengkap.

\subsection{Kalimat Larangan Pasif}

Kalimat larangan pasif kehadiran konstituen subjek tidak berstatus argumen, tetapi berstatus argumen objektif. Perhatikan contoh berikut ini.

(10) Dhuwite lemah

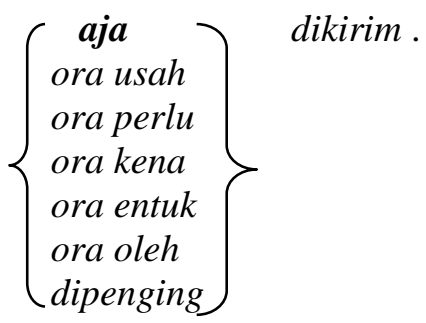

'Uangnya tanah jangan dikirim'

(11) Wedhuse

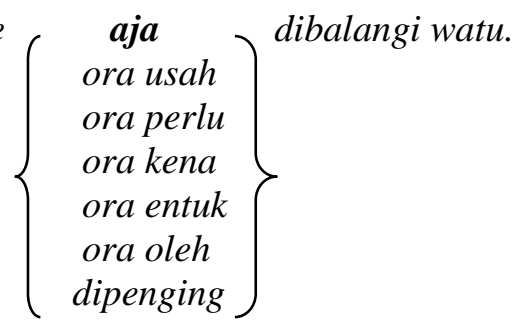

'Kambingnya jangan dilempari batu'

(12) Bayimu $\left\{\begin{array}{c}\text { aja } \\ \text { ora usah } \\ \text { *ora perlu } \\ \text { ora kena } \\ \text { ora oleh } \\ \text { ora entuk } \\ \text { dipenging }\end{array}\right\}$

'Bayimu jangan ditidurkan di tikar'

(13) Dolanane anakmu $\left\{\begin{array}{c}\text { aja } \\ \text { ora usah } \\ \text { ora perlu } \\ \text { ora kena } \\ \text { *ora entuk } \\ \text { *ora oleh } \\ \text { *dipenging }\end{array}\right\}$

'Mainan anakmu jangan kamu sembunyikan'

(14) Sepedhane $\left\{\begin{array}{l}\text { aja } \\ \text { ora usah } \\ \text { ora perlu } \\ \text { ora kena } \\ \text { *ora entuk } \\ \text { *ora oleh } \\ \text { *dipenging }\end{array}\right\}$ kokdol.

'Sepedanya jangan kamu jual'

Konstituen dhuwite lemah 'uangnya tanah', wedhuse 'kambingnya', bayine 'bayine', dolanane anakmu 'mainan anakmu', dan sepedhane 'sepedanya' pada kalimat (10) (14) mengisi fungsi subjek. Berdasarkan struktur perannya, beragumen objektif.

Kalimat larangan pasif menuntut kehadiran argumen agentif, namun kehadiran argumen agentif berbeda dengan argumen agentif yang terdapat pada kalimat larangan aktif. Argumen agentif yang ada pada kalimat 
larangan pasif secara personal berupa kok/koyang melekat pada bentuk dasar pengisi fungsi predikat, seperti terlihat pada contoh kalimat (10) dan (14).

Kalimat larangan pasif kehadiran konstituen subjek tidak hanya berstatus argumen objektif, tetapi berstatus argumen benefaktif, lokatif, instrumental, dan reseptif, seperti pada contoh berikut.

(15) Anakmu $\left\{\begin{array}{c}\text { aja } \\ \text { ora usah } \\ \text { ora perlu } \\ \text { ora oleh } \\ \text { *ora kena } \\ \text { *ora entuk } \\ \text { Dipenging }\end{array}\right\} \quad$ diuja panjaluke

'Anakmu jangan dituruti permintaannya'

(16)

Samiyem $\left\{\begin{array}{c}\text { aja } \\ \text { ora usah } \\ \text { ora oleh } \\ \text { ora perlu } \\ \text { *ora kena } \\ \text { ora entuk } \\ \text { dipenging }\end{array}\right\}$ wenehi beras raskin.

'Samiyem jangan diberi beras raskin'

$$
\text { (17) Simbah }\left\{\begin{array}{c}
\text { aja } \\
\text { ora oleh } \\
\text { ora usah } \\
\text { ora perlu } \\
\text { *ora kena } \\
\text { ora entuk } \\
\text { *dipenging }
\end{array}\right\}
$$

'Nenekmu jangan dibeli baju kebayak'

Konstituen anakmu 'anakmu', Samiyem, dan simbahmu 'nenekmu' mengisi fungsi pada kalimat (15)-(17). Berdasarkan struktur perannya, konstituen pengisi fungsi itu beragumen benefaktif. Selanjutnya, kalimat larangan pasif kehadiran konstituen berstatus argumen lokatif, seperti contoh berikut.

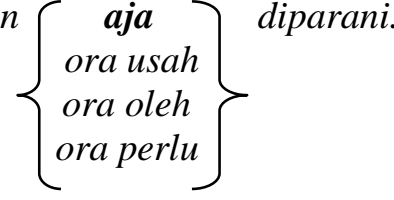

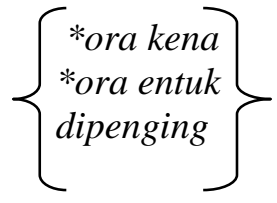

'Tagihan utangnya Atun jangan didatangi'

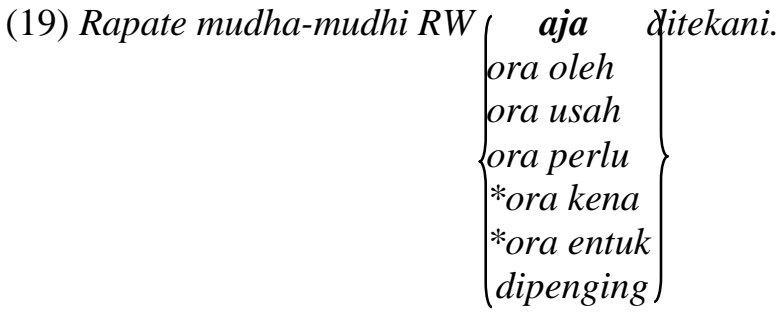

'Rapatnya muda-mudi RW jangan dihadiri'

Berdasarkan struktur perannya, konstituen Tagihan utange Atun 'tagihan utang Atun dan Rapate mudha-mudhi $R W$ 'rapatnya mudamudi RW' mengisi fungsi subjek berargumen lokatif.

Berdasarkan struktur perannya, konstituen sapu 'sapu' dan palu 'pukul besi' mengisi fungsi subjek pada kalimat (20) (21) di bawah ini berargumen instrumental. Untuk lebih jelasnya, perhatikan contoh berikut ini

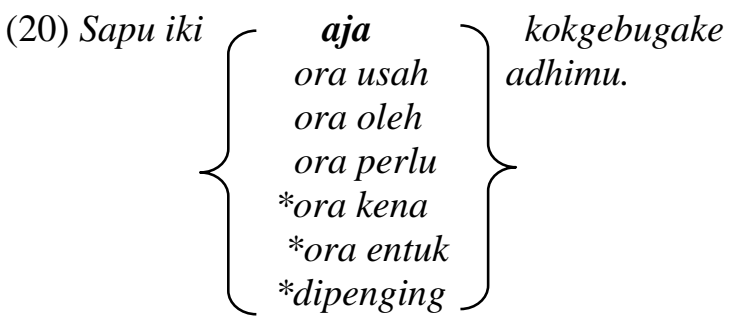

'Sapu ini jangan kau pukulkan adikmu.'

(21) Palu iki $\left\{\begin{array}{c}\text { aja } \\ \text { ora usah } \\ \text { ora oleh } \\ \text { ora perlu } \\ \text { ora kena } \\ \text { ora entuk } \\ \text { ora oleh } \\ \text { dipenging }\end{array}\right\}$

'Palu ini jangan dipukulkan batu.'

Selanjutnya contoh , konstituen subjek berargumen reseptif pada kalimat (22) dan (23), seperti contoh di bawah ini. 
(22) Jendhelane

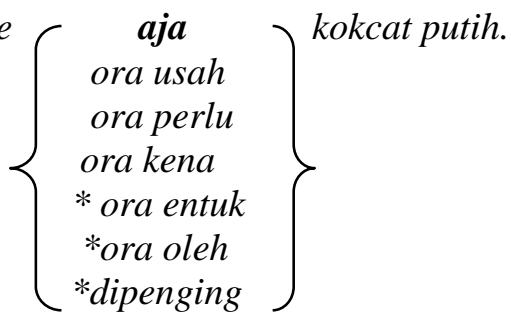

'Jendelanya jangan dicat putih'.

(23) Ibumu

$$
\left\{\begin{array}{c}
\text { aja } \\
\text { ora usah } \\
\text { ora perlu } \\
\text { ora kena } \\
\text { ora entuk } \\
\text { ora oleh } \\
\text { dipenging }
\end{array}\right\}
$$

'Ibumu jangan dimarahi'

Konstituen Jendhelane 'jendelanya' dan Ibumu 'ibumu' mengisi fungsi subjek berargumen reseptif.

Adapun ciri-ciri morfemis kata kerja pengisi fungsi predikat pada kalimat larangan pasif berupa kata kerja indikatif yang berawalan $d i$ - atau dapat pula berawalan kok/ko-, sedang akhirannya -ake dan -i ditemukan pada kalimat larangan aktif maupun kalimat larangan pasif tidak dapat dijadikan pembeda antara kedua jenis kalimat itu.

\subsection{Kalimat Larangan Resiprokal}

Fungsi subjek pada kalimat larangan resiprokal pada umumnya berupa konstituen yang menunjuk jamak, misalnya, kowe kabeh 'kamu semua', kowe saklaron 'kamu berdua', kowe karo aku 'kamu dan saya', kowe karo dheweke 'kamu dan dia', dan kowe karo adhimu'.

Konstituen pengisi subjek pada kalimat larangan resiprokal dapat berargumen ganda, seperti contoh berikut.

(24) Kowe lan adhimu

$$
\left\{\begin{array}{l}
\text { aja } \\
\text { ora usah } \\
\text { ora perlu } \\
\text { ora kena } \\
\text { ora entuk } \\
\text { ora oleh } \\
\text { dipenging }
\end{array}\right\} \text { dolanan }
$$

'Kamu dan adikmu jangan pukul-pukulan kalau sedang bermain'.

Konstituen kowe 'kamu' dan adhimu 'adikmu'pada kalimat (24) berstatus argumen agentif dan argumen objektif. Kegandaan status argumen yang terdapat pada konstituen pengisi fungsi subjek pada kalimat itu berkaitan dengan contoh kata kerja pengisi fungsi predikatnya. Hal itu tercermin pada konstituen perbuatan antem-anteman 'pukulpukulan' dilakukan oleh kowe 'kamu dan adhimu 'adikmu'. Perbuatan itu saling ditujukan kepada keduanya ( kowe dan adhimu) dan pengidentifikasian status argumen pada pengisi fungsi subjek, sedangkan konstituen aja 'jangan' menunjukkan pelarangan terhadap perbuatan.

Berikut ini contoh lain, konstituen pengisi subjek pada kalimat larangan resiprokal berargumen agentif-objektif, seperti berikut ini.

(25) Kowe lan kanca-kancamu
surung-surungan. $\left\{\begin{array}{l}\text { aja } \\ \text { ora usah } \\ \text { ora perlu } \\ \text { ora kena } \\ \text { ora entuk } \\ \text { ora oleh } \\ \text { dipenging }\end{array}\right\}$

'Kamu dan teman-temanmu jangan saling mendorong.'

(26) Kakangmu lan kowe aja padudon yen pas kumpul ana ngomah.

$$
\left\{\begin{array}{l}
\text { ora usah } \\
\text { ora perlu } \\
\text { ora kena } \\
\text { ora entuk } \\
\text { ora oleh } \\
\text { dipenging }
\end{array}\right\}
$$

'Kakakmu dan kamu jangan saling bertengkar saja kalau pas berkumpul di rumah.'

Contoh kalimat (25)-(26) di atas konstituen pengisi fungsi subjek berargumen agentifobjektif. Berikut ini contoh kalimat larangan 
resiprokal berargumen agentif - benefaktif, seperti kalimat (27)—(28) berikut.

(27) Wayah lebaran adhi-adhimu aja jejaluk dhuwit ana tangga teparo.

$$
\left\{\begin{array}{c}
\text { ora usah } \\
\text { ora perlu } \\
\text { ora kena } \\
\text { ora entuk } \\
\text { ora oleh } \\
\text { dipenging }
\end{array}\right\}
$$

'Saat lebaran adk-adik jangan meminta-minta uang di tetangga.'

(28) Kowe lan tanggamu aja ijol-ijolan seragam sorjan.

$$
\left\{\begin{array}{l}
\text { ora usah } \\
\text { ora perlu } \\
\text { ora kena } \\
\text { ora entuk } \\
\text { ora oleh } \\
\text { dipenging }
\end{array}\right\}
$$

'Kamu dan tetanggamu jangan saling menukar seragam sorjan.'

Selanjutnya, konstituen pengisi fungsi subjek pada kalimat larangan resiprokal berargumen agentif-reseptif, seperti contoh berikut.

(29) Yen wayahe UAS, kowe lan kancamu aja takon-tinakonan.

$$
\left\{\begin{array}{l}
\text { ora usah } \\
\text { ora perlu } \\
\text { ora kena } \\
\text { ora entuk } \\
\text { ora oleh } \\
\text { dipenging }
\end{array}\right\}
$$

'Kalau saatnya UAS kamu dan temanmu jangan saling bertanya.'

(30) Bocah papat iku yen mulih sekolah enten-entenan.

aja

$$
\left\{\begin{array}{l}
\text { ora usah } \\
\text { ora perlu } \\
\text { ora kena } \\
\text { ora entuk } \\
\text { ora oleh } \\
\text { dipenging }
\end{array}\right\}
$$

'Keempat anak itu kalau pulang sekolah jangan saling menunggu.'

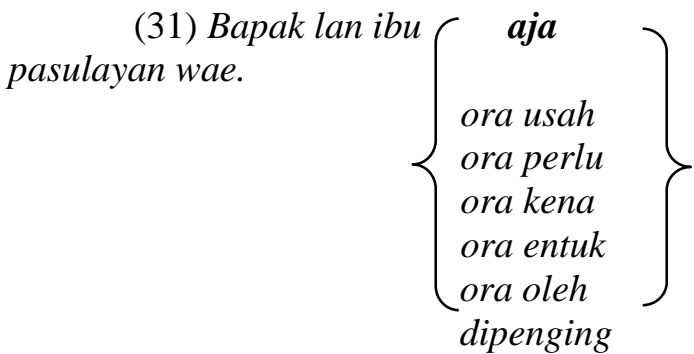

bertengkar saja.'

'Bapak dan ibu jangan saling

Berdasarkan contoh kalimat (24) (31) bahwa konstituen pengisi fungsi predikat pada kalimat larangan resiprokal memiliki ciri-ciri morfemis, yaitu berupa reduplikasi kata kerja.

\subsection{Kalimat Larangan Refleksif}

Kalimat larangan refleksif menuntut kehadiran pengisi fungsi subjek. Peran refleksif sebagai salah satu peran konstituen pusat menyatakan tindakan yang dinikmati oleh yang bertindak sendiri. Jadi, subjek berbuat dirinya sendiri, seperti contoh berikut.

(32) Radit aja lungguhneng meja tamu.

$$
\left\{\begin{array}{l}
\text { ora usah } \\
\text { ora perlu } \\
\text { ora kena } \\
\text { ora entuk } \\
\text { ora oleh } \\
\text { dipenging }
\end{array}\right\}
$$

'Radit jangan duduk meja tamu'

(33) Kowe menyang masjid sepatonan nganggoa sandal wae.

$$
\left\{\begin{array}{l}
\text { ora usah } \\
\text { ora perlu } \\
\text { ora kena } \\
\text { ora entuk } \\
\text { ora oleh } \\
\text { dipenging }
\end{array}\right\}
$$


'Kamu pergi ke masjid jangan bersepatu pakailah sandal saja'.

$\begin{array}{ll}\begin{array}{l}\text { (34) Drian } \\ \text { mabukan. }\end{array} & \left.\begin{array}{c}\text { srawung karo bocah } \\ \text { ora usah } \\ \text { ora perlu } \\ \text { ora kena } \\ \text { ora entuk } \\ \text { ora oleh } \\ \text { dipengin }\end{array}\right\}\end{array}$

'Drian jangan bergaul dengan anak pemabuk.'

(35) Budi aja nyiksa awakmu saben dina pasa .

$$
\left\{\begin{array}{l}
\text { ora usah } \\
\text { ora perlu } \\
\text { ora kena } \\
\text { ora entuk } \\
\text { ora oleh } \\
\text { dipenging }
\end{array}\right\}
$$

'Budi jangan menyikasa tubuhmu tiap hari puasa.'

Konstituen pengisi subjek pada kalimat (32) - (35) Radit, kowe, Drian, dan Budi berargumen agentif dan objektif. Fungsi subjek tersebut melakukan perbuatan untuk dirinya sendiri.

Kegandaan status argumen konstituen pengisi fungsi subjek pada kalimat refleksif ada kaitannya dengan contoh pengisi fungsi predikatnya, sedang kaitannya dengan penanda perintah aja 'jangan' menunjukkan sebagai larangan terhadap perbuatan yang tercermin pada kata kerja pengisi fungsi predikatnya.

Kegandaan status argumen konstituen pengisi fungsi subjek pada kalimat refleksif pada contoh kalimat (32) dan (35) menunjukkan gabungan argumen agentifobjektif. Contoh pada kalimat (33) dan (34) menunjukkan gabungan argumen agentifbenefaktif.

Di samping itu, perlu diketahui pula bahwa kegandaan argumen pengisi fungsi subjek pada kalimat larangan refleksif tidak sepenuhnya ditentukan oleh ciri-ciri morfemis kata kerja pengisi fungsi predikatnya, tetapi ditentukan pula oleh watak semantisnya.

\section{Simpulan}

Berdasarkan kajian di atas dapat disimpulkan sebagai berikut.

Kalimat larangan ditandai penanda perintah aja 'jangan', serta konstituen ora oleh 'tidak boleh', dipenging 'dilarang', ora usah 'tidak usah', ora perlu 'tidak perlu', ora kena 'tidak boleh', dan ora entuk 'tidak boleh'

Kalimat larangan bahasa Jawa memiliki kalimat bawahan yang mengacu pada diatesis bahasa Jawa, yaitu (i) diatesis aktif, (ii) diatesis pasif, (iii) diatesis resiprokal, dan (iv) diatesis refleksif.

Kalimat laranagn bahasa Jawa meliputi (a) kalimat larangan aktif, (b) kalimat larangan pasif, (c) kalimat larangan resiprokal, dan (d) kalimat larangan refleksif.

Kreteria pembeda subjenis kalimat larangan yang satu dengan kalimat larangan yang lainnya, yaitu (1) status argumen konstituen pengisi fungsinya, (2) watak leksikal kata kerja pengisi fungsi predikatnya, dan (3) ciri-ciri morfemis kata kerja pengisi fungsi predikatnya.

Status argumen pada kalimat larangan meliputi (a) kalimat larangan aktif berstatus argumen agentif, (b) kalimat larangan pasif berstatus argumen objetif, (c) kalimat larangan resiprokal berstatus argumen ganda agentif - objektif, agentif - benefaktif, dan agentif - reseptif, dan (d) kalimat larangan refleksif berstatus argumen ganda, yaitu agentif - objektif dan agentif - benefaktif.

Ciri morfemis kata kerja pengisi fungsi predikatnya meliputi (i) kata kerja indikatif yang berprefiks $\mathrm{N}$-, (ii) kata kerja indikatif yang berprefiks $d i$-, $k o k / k o$-, dan (iii) reduplikasi kata kerja, dan (iv) kata kerja indikatif.

\section{Daftar Pustaka}

Alwi, Hasan. 2003. Tata Bahasa Baku Bahasa Indonesia. Jakarta: Balai Pustaka.

Antunsuhono. 1956. Reringkesaning Parasastra Djawa II. Yogyakarta: Hien HooSing.

Herawati. 1990/1991. "Kalimat Perintah dalam Bahasa Jawa". Yogyakarta: Yogyakarta: Balai Bahasa. 
2007. Negasi dalam Bahasa Jawa.

Yogyakarta: Grafindo Litera Media.

Kridalaksana, Harimurti. 2001. Kamus Linguistik. Jakarta: PT Gramedia Pustaka Utama.

Lyons, John. 1969. Introduction to Theoretical Linguistics. London: Cambridge University Press.

Poedjosoedarmo, Soepomo. 1979. Morfologi Bahasa Jawa. Jakarta Pusat Pembinaan dan Pengembangan.

Poerwadarminta, W.J.S. 1953. Baoesastra Djawa. Groningen Batavia: B. Wolters Uitgevers, Maatschappij.

Ramlan. M.1987. Ilmu Bahasa Indonesia: Sintaksis. Yogyakarta: CV. Karyono.
Sudaryanto. 1982. Metode Linguistik:

Kedudukannya, Aneka

Jenisnya, dan Faktor

Penentu Wujudnya.

Yogyakarta: Fakultas Sastra dan Kebudayaan, UGM.

1983. Predikat-Objek dalam

Bahasa Indonesia:

Keselarsan Pola Urutan. Seri

ILDEP. Jakarta: Jambatan.

et al. .1991. Diatesis dalam

Bahasa Jawa. Jakarta:

Departemen Pendidikan

dan Kebudayaan. 